\title{
Influence of surface geology and micro-scale land use on the shallow subsurface salinity in deltaic coastal areas: a case from southwest Bangladesh
}

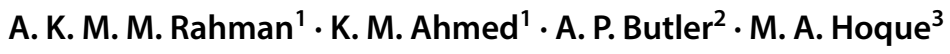 \\ Received: 26 June 2017 / Accepted: 2 June 2018 / Published online: 18 June 2018 \\ (c) The Author(s) 2018
}

\begin{abstract}
Salinity, both in soil and water, is a ubiquitous problem in coastal Bangladesh, particularly in the southwest. Salinity varies at the local scale $(5-10 \mathrm{~m})$, but the relative roles of land use and surface geology on salinity variation in near-surface $(<5 \mathrm{~m})$ groundwater are not fully understood. Surface geology, land use and salinity in near-surface (ca. $3 \mathrm{~m}$ ) groundwater at two small sites (each $0.05 \mathrm{~km}^{2}$ ) were explored in the southwest coastal region of Bangladesh. The sediments in the near-surface at both sites are fine and hydrometer analyses of cored samples indicate the dominance of silty clay (70\%) along with very fine sand (5\%), sandy clay (15\%) and clay (10\%) materials. Salinity variation in near-surface groundwater tends to follow land use rather than surface geology at the scale of our investigations. The study provides evidence of the influence of land use on the near-surface salinity variation and indicates the importance of land-use planning in salinity management in coastal areas.
\end{abstract}

Keywords Bangladesh $\cdot$ Polder $\cdot$ Groundwater $\cdot$ Salinity $\cdot$ Land use $\cdot$ Delta

\section{Introduction}

Coastal areas are one of the most productive regions in the world where millions of people live and produce agricultural goods (Glantz 1992). Maintaining the quality of surface water as well as groundwater is a major challenge in such areas as they are vulnerable to coastal environmental changes (Hoque et al. 2016). Situated in the world's largest river system delta, the Ganges-Brahmaputra-Meghna, Bangladesh is vulnerable to coastal hazards. Its coasts, like other tropical deltas, are regularly battered by the landfall of episodic cyclones (Islam and Peterson 2008; Karim and

Electronic supplementary material The online version of this article (https://doi.org/10.1007/s12665-018-7594-0) contains supplementary material, which is available to authorized users.

M. A. Hoque

mo.hoque@port.ac.uk

1 Department of Geology, University of Dhaka, Dhaka, Bangladesh

2 Department of Civil and Environmental Engineering, Imperial College London, London, UK

3 School of Earth and Environmental Sciences, University of Portsmouth, Portsmouth, UK
Mimura 2008; Knapp et al. 2010). Recent storm surges associated with these cyclones, such as Sidr in 2007 and Aila in 2009, have left a trail of destruction and inundated large areas with sea water in the southwest coastal region of Bangladesh (Kibria et al. 2015). These inundations have resulted in widespread salinity problems in the area, including high soil salinities, which have led to a reduction in agricultural yield (Dasgupta et al. 2015). Future rising sea levels coupled with embanked landscape and reduced up-stream flow (Mirza 1998) will most likely increase the area of inundation from similar surges (Bhuiyan and Dutta 2012; Dasgupta et al. 2009; Karim and Mimura 2008; Singh 2002).

The southwest coastal area of Bangladesh is drained by numerous distributaries of the Ganges River, which carry large quantities of water and sediment from the Himalayan ranges. Fluvio-tidal action redistributes the enormous amount of sediment carried by these rivers in the southwestern coastal belt and in the Sundarban mangrove forest (Goodbred and Kuehl 1998). The entire area is characterised by fine sediments and is known to contain 5- to 10-m-thick silty clay layers at the surface confining the underlying sandy aquifer, which is mostly saline (Worland et al. 2015). There are a number (ca. 50) of intertidal and forested islands located at the northern border of the forest. These islands were enclosed with embankments to reclaim 
lands for agriculture in the 1960s (The World Bank Group 2010), which were natural tidal plains until then (Willcocks 1930). Coastal polders influence natural sedimentation leading to an elevation difference in- and out-side the polders (Auerbach et al. 2015; Islam et al. 2018). These polders (4.5-5.5 m high) are often breached or overtopped by cyclonic surges allowing polder areas to be flooded with sea water. The land use in the polder is mainly characterised by agricultural land. In the recent past there were also substantial numbers of shrimp farms, but these are now in decline. A much smaller area is comprised of human settlements, which also contain purpose-built drinking water ponds that harvest rainwater. The settlement areas are of a similar height to the polders and drinking water ponds, generally 3-4 m deep, and are located within those inhabited areas. The salinity of the groundwater is often marginally higher than guideline irrigation water quality $(2000 \mathrm{mg} / \mathrm{L}$ salt concentration), and therefore, dry-season irrigation is restricted to limited surface water storage that accumulates during the rainy season within the drainage channels in those polders. It is popularly believed (Ali 2006; Paul and Vogl
2011) that the shrimp farming has led to the build-up of the salinity in the area. However, the influence of near-surface geology, i.e. variation in lithology, on the distribution of salinity in the near surface is not known.

To investigate these influences, two typical small areas (totalling ca. $0.1 \mathrm{~km}^{2}$ ) were chosen in the Dacope Upazila of southwest coastal district Khulna in Bangladesh (Fig. 1). One of the sites (DAB) is located outside Polder 31 and another (DAS) is inside Polder 32. At DAB a tidal river (Vadra R.) passes beside it and, due to the extent of the river floodplain, some parts of the site are inundated twice a day. Moreover, the drinking water pond is surrounded by brackish water (9000-10,000 $\mu \mathrm{S} / \mathrm{cm}$ electrical conductivity) in which there are shrimp and crab cultivation fields on three sides. The other site (DAS) is $100 \mathrm{~m}$ away from the river and is located behind a polder embankment. This site is therefore protected from any saline influx from regular tidal water, although a sluice gate is used to control the inflow of river water for cultivation purposes during the rainy season. Both sites represent relatively small areas of land that include typical variations of land use in coastal Bangladesh. The
Fig. 1 Study area and microscale land-use variation at two studied sites in southwest Bangladesh. a DAB site is located outside Polder 31; b DAS site located inside Polder 32. The sites are around $6 \mathrm{~km}$ apart as shown on the Google Earth image in the upper left panel. Profiles are indicating the lines of lithological sections shown in Fig. 3 using hand flap drilling data
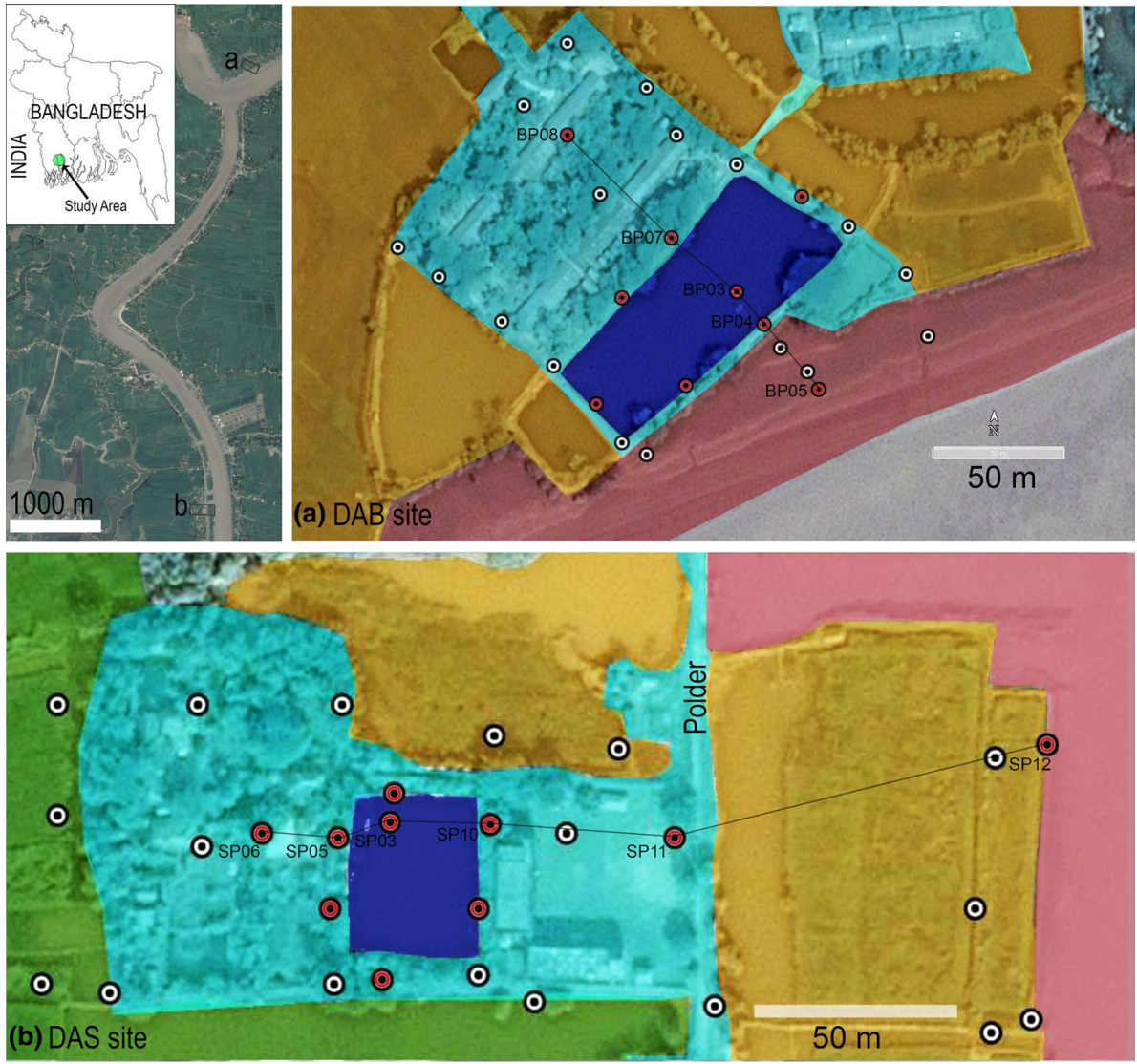

Legend

Agricultural Land

Drinking Water Pond

High / Build Up Area

Saline Pond / Shrimp Farm
Tidal Plains

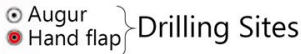


aim of this study is to characterise the small-scale variation of land use and geology and their association with the spatial distribution of shallow (ca. 3-4 mbgl) groundwater salinity.

\section{Description of the study area}

Morphologically the coastal area, where the sites are located, is dynamic and characterised by numerous tidal rivers. These rivers regularly experience semi-diurnal tides with amplitudes of around a couple of metres. After the landfall of cyclone Aila in 2009, Polder 32 in Dacope was flooded by seawater and large parts of the enclosed area remained submerged for 2 years, whilst the breach in the polder embankment was awaiting repair (Auerbach et al. 2015). The area is characterised by hot, rainy monsoonal summers (May-October) and dry winters (November-April). During summer months the area gets over $90 \%$ of its ca. $1700 \mathrm{~mm}$ /year rainfall, while yearly evapotranspiration is ca. $1000 \mathrm{~mm}$.

The hydrogeology of the study area is characterised by unconsolidated Quaternary sediments with a semi-confined aquifer within $10 \mathrm{~m}$ below ground surface overlain by a significantly thick (3-7 m) near-surface clay and silty clay layer. The shallow aquifer (between 10 and $50 \mathrm{~m}$ ) has variable salt concentrations typically not less than $1500 \mathrm{mg} / \mathrm{L}$ and generally ca. over $3000 \mathrm{mg} / \mathrm{L}$. The high groundwater salinities dictate local inhabitants to rely on less saline ponds, canals, rivers, etc., as alternative water sources (Benneyworth et al. 2016; Islam et al. 2013; Khan et al. 2011; Scheelbeek et al. 2017; Worland et al. 2015). It also means that use of the groundwater for irrigation is relatively low compared to other parts of the country. During the monsoon, rainwater harvesting provides an additional water resource in the region. Furthermore, Managed Aquifer Recharge (MAR) has also been utilised, where rainwater is stored artificially in the shallow aquifer for the use during the dry season (Sultana et al. 2015).

\section{Methods and materials}

\section{Lithology and salinity measurements}

Sediment characteristics were obtained from 59 locations using "hand flap" drilling and hand auger carried out between July 2013 and April 2014 (Fig. 1). At the site DAB, drilling was continued up to a depth of 3-3.5 m below the ground surface, while at DAS it was 6-6.5 m. At both sites, a water table was encountered and at the final depth of each drilling location electrical conductivity (EC), as a surrogate for salinity, was measured using a Solinst TLC meter. A simple hand auger was used to drill 36 holes. At every site, a lithological log, at $30.5 \mathrm{~cm}$ intervals down to the depth of the water table, was recorded. Sediment samples, gathered from drilling, were collected and stored in plastic bags to analyse in the laboratory.

\section{Grain-size analysis}

All the collected samples were analysed in the laboratory using the hydrometer method for grain-size distribution (Bouyoucos 1962). A 4\% Calgon solution (40 g sodium hexametaphosphate $+960 \mathrm{~g}$ of water) was made up and then $50 \mathrm{~g}$ of sample was taken and soaked in $125 \mathrm{~g}$ of Calgon solution for 8-12 h. Then in a cylinder, water was mixed with soaked samples and poured up to $1000 \mathrm{~mL}$. The mixture was stirred for a minute and then density measurements were taken using an ASTM Soil Hydrometer $152 \mathrm{H}$ at intervals of 2, 4, 8, 15, 30, 60, 120, 240 and $1440 \mathrm{~min}$. Finally, after washing, sample sieve residue was preserved and dried. One of the calculated grain-size percentages is presented in Fig. 2 and all data is given in online supplementary information (Table S1).
Fig. 2 Graphical projection of grain sizes percentage as derived using hydrometer method. All the processed grain-size data including estimates of hydraulic conductivities are given in the supplementary information, Table S1

\section{Grain-size Analysis}

$\leadsto$ BP08 D-3 m(Sand 4\%, Silt 72\%, Clay $24 \%$ ) 


\section{Bulk density and hydraulic conductivity}

Given the high similarity in the lithologies at the two sites, bulk density measurements $(n=6)$ were only made at the DAB site. Sediment samples were obtained using $10 \mathrm{~cm}(4$ in.) long PVC tubes inserted into the ground to a depth of $30-46 \mathrm{~cm}$ (1-1.5 feet). $5 \mathrm{~cm}$ (2 in.) diameter cores were extracted from these tubes for analysis. The weight of PVC tube was measured beforehand and after the tube was preserved to keep the samples undisturbed after collection. In the laboratory, wet bulk density of the sediment was calculated according to following formula:

$\rho_{\mathrm{b}}=\frac{M}{V}$,

here $\rho_{\mathrm{b}}=$ bulk density $\left(\mathrm{g} / \mathrm{cm}^{3}\right), M=$ mass of the sediment $(\mathrm{g})=($ mass of the tube with sediment - mass of the tube), $V=$ internal volume of the tube $\left(\mathrm{cm}^{3}\right)$.

The hydraulic conductivities of the sediment samples were estimated using ROSETTA 1.1, a computer program to estimate unsaturated hydraulic properties from surrogate soil data such as soil texture data and bulk density (Schaap et al. 1998), available through the Hydrus 1D-an open source computer package (Simunek et al. 2008).

\section{Land use}

Land-use maps of the study sites (Fig. 1) were made by using Google Earth satellite images of October 2014. Different land-use types such as-agricultural land, human settlement, water-body, ponds, saline ponds for shrimp farming and tidal floodplain were identified based on enumerated features and field validation.

\section{Results}

\section{Lithological variation}

The shallow subsurface of the sites is characterised by clay, silty-clay, sandy-clay and, rarely fine sands, up to the maximum depth of sampling, (Fig. 3). Spatial lithological variability at the scale of our investigations is minimal at both sites and similar geological materials were encountered.

\section{Grain-size variation}

Silty/sandy clay is the main lithology at shallow depth in this region. Using textural soil classification triangles, developed by Gerakis and Baer (1999), a sediment classification of the shallow subsurface has been established as shown in Fig. 4 for both sites. Almost similar textural properties, silt loam and silty clay loam, have been observed. The exceptions
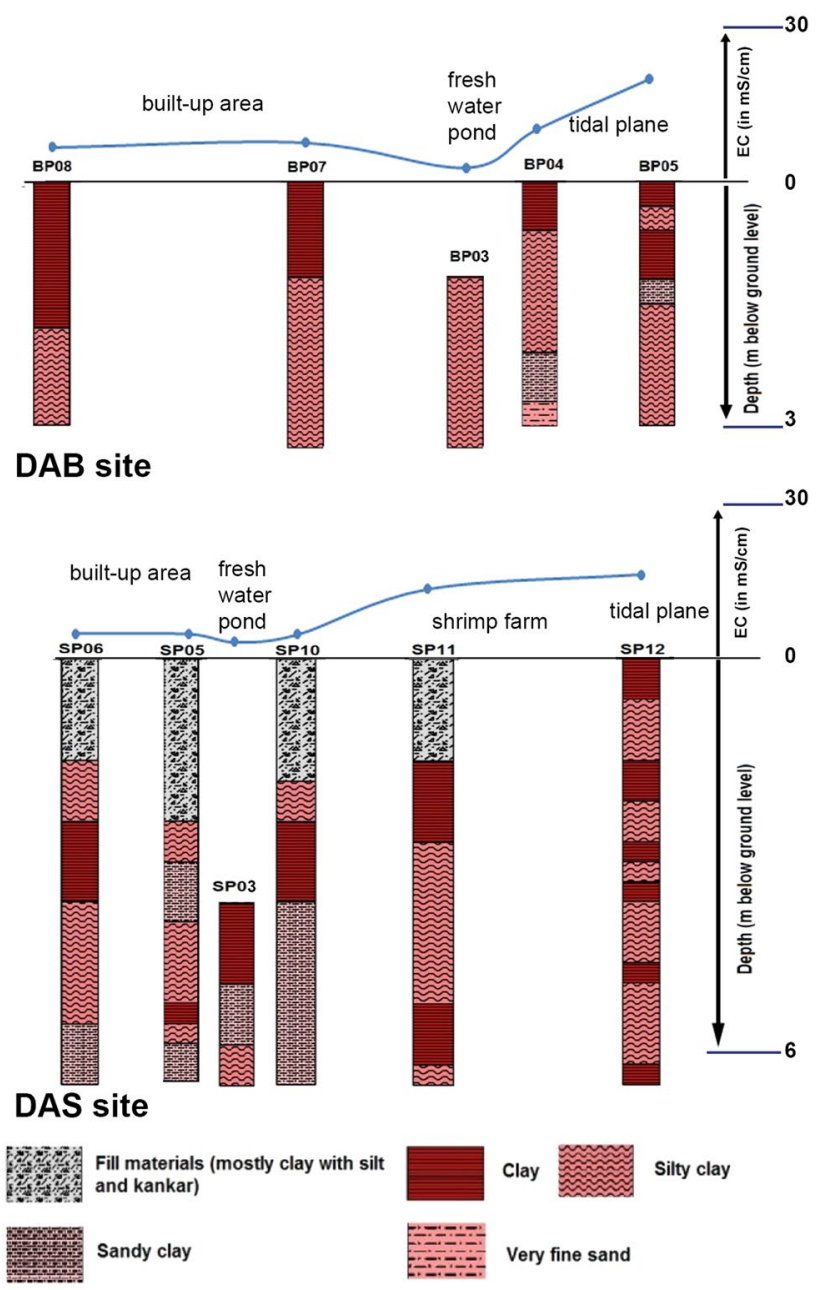

Fig. 3 Representative lithologs along W-E sections (see location in Fig. 1) from both sites indicate the dominance of fine sediment. Both panels contain land use as they appear in Fig. 1. The EC variation indicate that land use has a role in controlling the underlying salinity at shallower depths

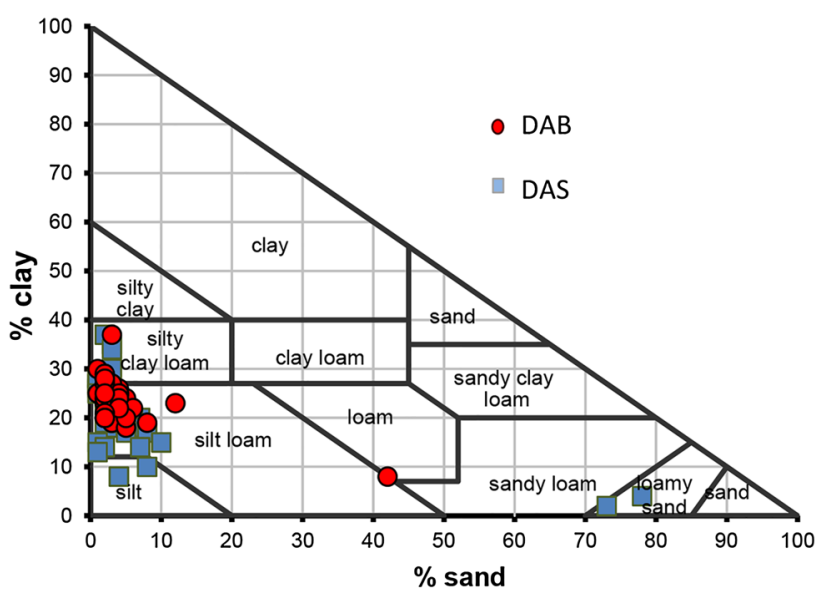

Fig. 4 Textural classification of sediment samples collected at both the sites. Both sites are dominated by silt loam 
were a location in $\mathrm{DAB}$, where loam was encountered at a depth of $2.5 \mathrm{~m}$, and one at DAS, where loamy sand underlying silt loam was found below the pond at this site at a depth range from $3.9 \mathrm{~m}$ to $4.25 \mathrm{~m}$.

\section{Bulk density and hydraulic conductivity}

The wet bulk density of the sediment samples $(n=6)$ ranged between 2.33 and $2.37 \mathrm{~g} / \mathrm{cm}^{3}$. On average the bulk density of the near-surface materials is $2.35 \mathrm{~g} / \mathrm{cm}^{3}$. The estimated hydraulic conductivity in different layers at both sites ranges between 0.2 and $0.9 \mathrm{~cm} /$ day with a similar distribution pattern (Fig. 5). The median hydraulic conductivity is $0.37 \mathrm{~cm} /$ day with an inter-quartile range of 0.16 .

\section{Land use and salinity}

The salinity of the groundwater was measured just after the auger drilling and (in the piezometers) at hand flap drilled locations. The electrical conductivity varied from the river to inland area was about $17,400-26,800 \mu \mathrm{S} / \mathrm{cm}$ near or beside the river and dropped to $4100-5500 \mu \mathrm{S} / \mathrm{cm}$ in the inland area (Fig. 6). Transects from river to the inland at both sites indicate some variation in salinity while lithologies and hydraulic conductivities are comparable. The salinity contours indicate two dominant spatial patterns with areas of relatively low salinity and high salinity.

\section{Discussion}

\section{Surface geology and land use}

The local lithological results are consistent with larger scale sedimentary analyses from the area. Silty clay (along with clay and sandy clay) is the principal constituent of the near surface in the Bengal coastal region, as a result of the complex tidal depositional regime (Allison et al. 2003). Due to the low hydraulic conductivities of these laterally extensive sediments ( $\sim 0.3 \mathrm{~cm} /$ day $)$, it might be anticipated that they would act as a 'hydraulic barrier' to the downward movement of water, whether from seawater inundation or monsoonal rainfall (Yu 2010). However, in spite of this, variations in salinity are observed at both study sites.

Agriculture, mostly rice farming, is the main source of income for the population living in these reclaimed (polder) lands. However, areas close to the polder embankments are often used for shrimp farming instead, where brackish water is ponded year-round (Johnson et al. 2016; Paul and Vogl 2011). At both study sites, land use is characterised by agricultural land inside the polders, while outside the polder shrimp farming is dominant (Fig. 1). In both cases, communities tend to live on the slightly higher ground both inside the polder and (at DAB) outside of the polder. Drinking water ponds are predominantly used for water supply, due to the high salinities in groundwater. Whilst protected from seawater inundation due to the polder embankment or, if outside, on the ground above the normal range of tidal level, the drinking water ponds remain relatively fresh. Land-use variations at the study sites can be divided into three distinct types: areas with almost constant saline water ponding (shrimp farm/tidal flat), drinking water ponds containing relatively fresh water, and habited areas which are located above the normal tidal (saline water) range.

A relatively large scale $\left(70 \mathrm{~km}^{2}\right)$ study (Worland et al. 2015) in Polder 32 interpreted salinity in shallow groundwater (between 20 and $50 \mathrm{mbgl}$ ) as a Holocene syn-depositional feature and subsequent slow infiltration of meteoric water led to freshening of the aquifer in areas where near-surface geology is relatively permeable. We identified that the influence of surface water salinity (associated with different land use) on the groundwater
Fig. 5 Histogram of hydraulic conductivity derived from the grain-size analysis as in Fig. 4. a At DAB site $(n=47)$, and $\mathbf{b}$ DAS site $(n=40)$
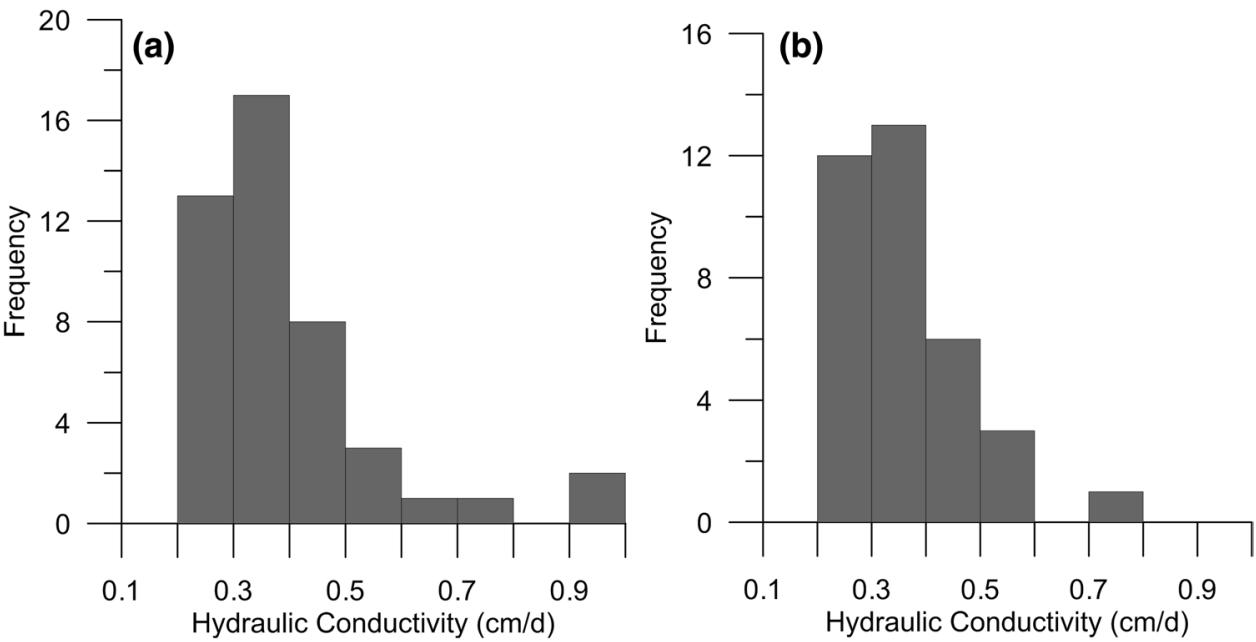
Fig. 6 Link between the salinity with the land use: a DAB and b DAS sites. The land-use classifications are similar to Fig. 1. The salinity is significantly lower in areas overlain by the fresh-water ponds. The contours were generated using kriging interpolation

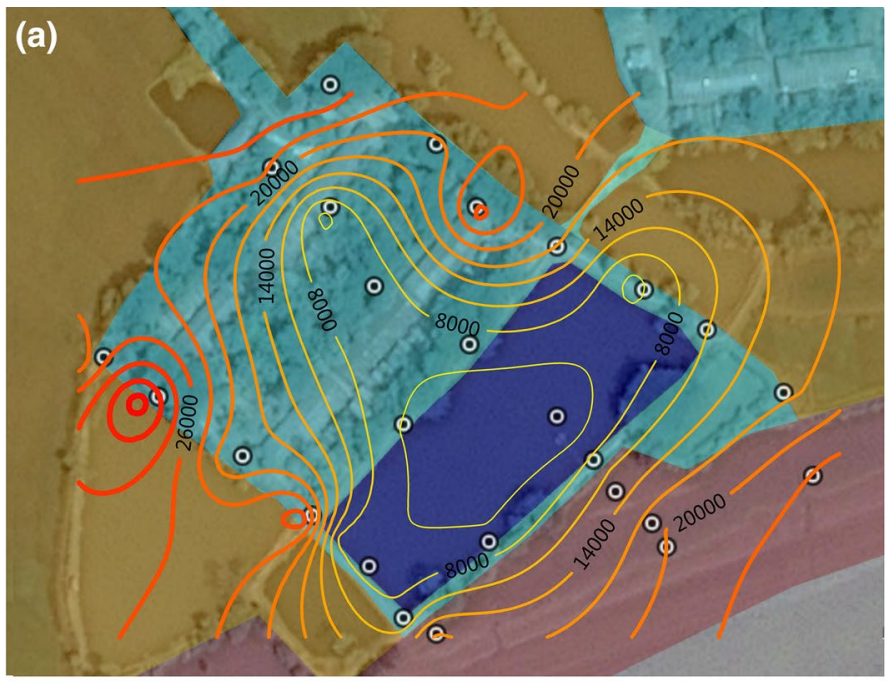

\section{$\mathrm{EC}(\mu \mathrm{S} / \mathrm{cm})$}

2000

5000

8000

11000

14000

17000

20000

23000

26000

29000

32000

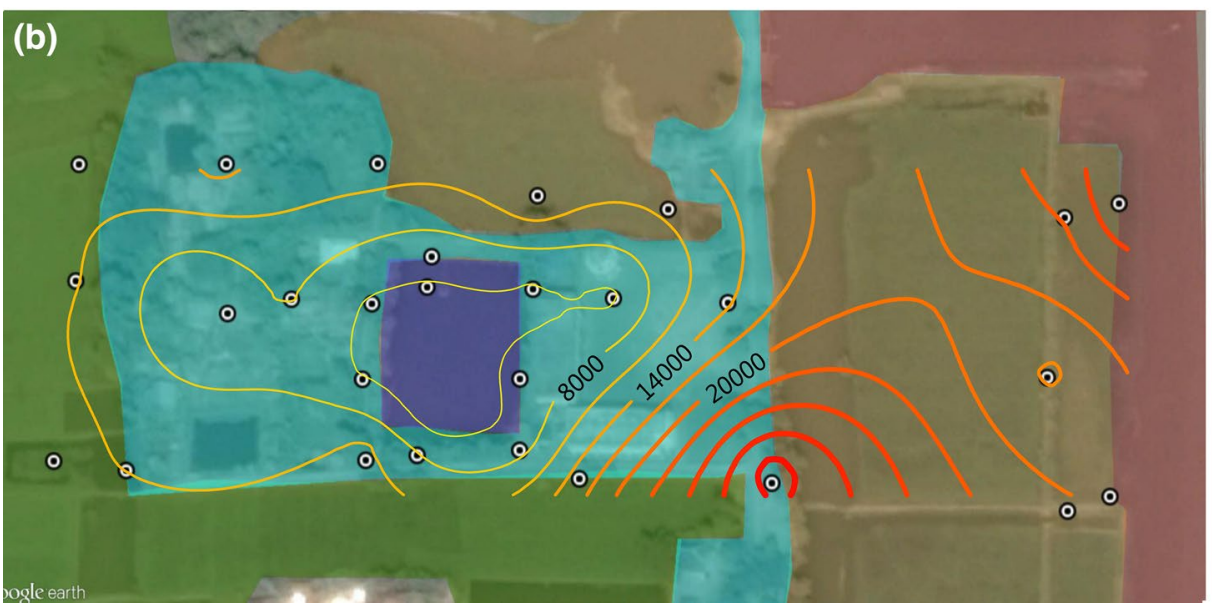

salinity regime is pervasive. We found areas underlying the shrimp farm/tidal flat contain higher salinities irrespective of the surface geology while areas underlying the aforesaid drinking water ponds or habitated areas have relatively low salinity. Although the geology is similar, the thickness of the fine sediment layer below the ponds was relatively lower compared to the other land-use areas. Therefore, the infiltration rate is likely to be higher leading to a freshening of the salinity below the pond. It was also observed that a saline plume develops underneath the pond when there is saline water intrusion into the pond (unpublished data, Hoque MA). On the contrary, underlying areas in and around the shrimp farm, where saline water ponding is present, possess high salinity even with a thick fine-grained intervening layer. Salinity management in these areas is effectively related to land-use planning and to avoiding ponding of saline surface water.

\section{Land use and salinity}

Particle size analyses show no substantial variation in lithology over the two sites. On the other hand, measurements in salinities indicate an association with land-use pattern (Figs. 3, 6). Salinity levels at the water table are lower in areas where land use is associated with low salinity water (i.e. ponds) or at locations above the normal tidal range, whereas higher salinities are prevalent in areas where there is surface ponding of saline water.

Field observations (Hoque et al. 2015) have indicated that there tends to be a downward hydraulic head gradient between surface water and shallow groundwater. This downward gradient allows surface water to infiltrate vertically, albeit at a slow rate. Assuming the salinity of water infiltrating at the surface remains reasonably constant, it would be expected that over time the salinity at the water table would be similar to that at the surface. For a vertical hydraulic head 
gradient of around unity, the infiltration rate is roughly the same as the hydraulic conductivity. Therefore, for a value of $0.3 \mathrm{~cm} /$ day, and an estimated porosity of around 0.4 for this uncompacted soft sediment (e.g. Das 2008), the time of travel for a conservative ion to move down $3 \mathrm{~m}$ is just over a year. This supports the inference that salinity at shallow depth is related to salinity associated with land use. This would seem reasonable as the only major perturbation of salinity at the surface is from widespread inundation from a storm surge associated with a tropical cyclone. However, 4-5 years had elapsed between a last such inundation from cyclone Aila and sampling (2013/2014), and ponds affected were remediated the following year.

Distance from the river can also be seen as a factor but in reality, a more likely factor is the presence of saline water in the river compared to the other areas. Again, similar reasoning can be made for having higher salinities in shallow groundwater outside the polder where (except for locations where people are living on slightly raised ground) everything is flooded during high tide or saline water is intentionally ponded for shrimp cultivation fields (EC 12,000-36,000 $\mu \mathrm{S} /$ $\mathrm{cm}$ ) (Fig. 6). The community mound and other built-up areas are on the relatively higher ground, contain fill materials, and may provide fresh water recharge areas during the rainy season. Vertical recharge may diminish the salinity in underlying shallow groundwater and in both sites we find the EC ranging between 4000 and $8000 \mu \mathrm{S} / \mathrm{cm}$. However, the marginal areas in those mounds adjacent to shrimp farms have higher salinity (Fig. 6), most likely due to the intrusion of salt water from shrimp farms.

\section{Implications}

This exploratory study indicated the importance of protecting enclosed polder areas from salt water flooding associated with storm surges as those can lead to widespread salinity of the soil leading to a decline in crop production (Rahman et al. 2011) and may also increase the cost of roads and infrastructure maintenance (Dasgupta et al. 2014). It also indicates that the confining layer, separating the aquifer and the surface land-use actions, may slow down the process but would not be able to stop the salinisation.

Shallow groundwater of the southwestern coastal belt is vulnerable because of climate change and so are other Asian deltaic coastlines (Hoque et al. 2016). Our study indicates a link between shallow salinity pattern and land use, at least at the scale of our interest, and signifies that land-use management could be an important factor in avoiding groundwater salinisation.

Acknowledgements The Leverhulme Trust (Grant no. RPG-314 to APB) and The Wellcome Trust (Institutional Strategic Support Fund:
Networks of Excellence Scheme 2014 to APB) are greatly acknowledged for the financial support received.

Open Access This article is distributed under the terms of the Creative Commons Attribution 4.0 International License (http://creativeco mmons.org/licenses/by/4.0/), which permits unrestricted use, distribution, and reproduction in any medium, provided you give appropriate credit to the original author(s) and the source, provide a link to the Creative Commons license, and indicate if changes were made.

\section{References}

Ali AMS (2006) Rice to shrimp: land use/land cover changes and soil degradation in southwestern Bangladesh. Land Use Policy 23(4):421-435

Allison MA, Khan SR, Goodbred SL Jr, Kuehl SA (2003) Stratigraphic evolution of the late Holocene Ganges-Brahmaputra lower delta plain. Sediment Geol 155:317-342

Auerbach LW, Goodbred SL Jr, Mondal DR, Wilson CA, Ahmed KR, Roy K, Steckler MS, Small C, Gilligan JM, Ackerly BA (2015) Flood risk of natural and embanked landscapes on the GangesBrahmaputra tidal delta plain. Nat Clim Change 5:153-157

Benneyworth L, Gilligan J, Ayers JC, Goodbred S, George G, Carrico A, Karim MR, Akter F, Fry D, Donato K et al (2016) Drinking water insecurity: water quality and access in coastal south-western Bangladesh. Int J Environ Health Res 26(5-6):1-17

Bhuiyan M, Dutta D (2012) Assessing impacts of sea level rise on river salinity in the Gorai river network, Bangladesh. Estuar Coast Shelf Sci 96:219-227

Bouyoucos GJ (1962) Hydrometer method improved for making particle size analyses of soils 1. Agron J 54(5):464-465

Das B (2008) Advanced soil mechanics. Taylor \& Francis, London

Dasgupta S, Laplante B, Meisner C, Wheeler D, Yan J (2009) The impact of sea level rise on developing countries: a comparative analysis. Clim Change 93(3-4):379-388

Dasgupta S, Hossain MM, Huq M, Wheeler D (2014) Climate change, groundwater salinization and road maintenance costs in coastal Bangladesh. World Bank, Washington

Dasgupta S, Hossain MM, Huq M, Wheeler D (2015) Climate change and soil salinity: the case of coastal Bangladesh. Ambio 44(8):815-826

Gerakis A, Baer B (1999) A computer program for soil textural classification. Soil Sci Soc Am J 63(4):807-808

Glantz MH (1992) Climate variability, climate change, and fisheries. Cambridge University Press, New York

Goodbred SL Jr, Kuehl SA (1998) Floodplain processes in the Bengal Basin and the storage of Ganges-Brahmaputra river sediment: an accretion study using ${ }^{137} \mathrm{Cs}$ and ${ }^{210} \mathrm{~Pb}$ geochronology. Sediment Geol 121(3-4):239-258

Hoque MA, Williams A, Mathewson E, Rahman AKMM., Ahmed KMSPFD., Vineis P, Butler AP (2015) Monitoring and modelling of salinity behaviour in drinking water ponds in southern Bangladesh. https://agu.confex.com/agu/fm15/meetingapp.cgi/ Paper/80571. Accessed 1 June 2017

Hoque MA, Scheelbeek PFD, Vineis P, Khan AE, Ahmed KM, Butler AP (2016) Drinking water vulnerability to climate change and alternatives for adaptation in coastal south and south east Asia. Clim Change 136(2):247-263

Islam T, Peterson RE (2008) Climatology of landfalling tropical cyclones in Bangladesh 1877-2003. Nat Hazards 48(1):115-135

Islam MA, Sakakibara H, Karim RM, Sekine M (2013) Potable water scarcity: options and issues in the coastal areas of Bangladesh. J Water Health 11(3):532-542 
Islam MR, Abdullah HM, Ahmed ZU, Islam I, Ferdush J, Miah MG, Miah MMU (2018) Monitoring the spatiotemporal dynamics of waterlogged area in southwestern Bangladesh using time series Landsat imagery. Remote Sens Appl Soc Environ 9:52-59

Johnson FA, Hutton CW, Hornby D, Lázár AN, Mukhopadhyay A (2016) Is shrimp farming a successful adaptation to salinity intrusion? A geospatial associative analysis of poverty in the populous Ganges-Brahmaputra-Meghna Delta of Bangladesh. Sustain Sci 11(3):423-439

Karim MF, Mimura N (2008) Impacts of climate change and sea-level rise on cyclonic storm surge floods in Bangladesh. Glob Environ Change 18(3):490-500

Khan AE, Ireson A, Kovats S, Mojumder SK, Khusru A, Rahman A, Vineis P (2011) Drinking water salinity and maternal health in coastal Bangladesh: implications of climate change. Environ Health Perspect 119(9):1328-1332

Kibria MG, Saha D, Kabir T, Naher T, Maliha S, Mondal MS (2015) Achieving food security in storm surge-prone coastal polders of south-west Bangladesh. South Asia Water Stud J 5(1):26-43

Knapp KR, Kruk MC, Levinson DH, Diamond HJ, Neumann CJ (2010) The international best track archive for climate stewardship (IBTrACS). Bull Am Meteorol Soc 91(3):363-376

Mirza QMM (1998) Diversion of the Ganges water at Farakka and its effects on salinity in Bangladesh. Environ Manag 22(5):711-722

Paul BG, Vogl CR (2011) Impacts of shrimp farming in Bangladesh: challenges and alternatives. Ocean Coast Manag 54(3):201-211

Rahman MH, Lund T, Bryceson I (2011) Salinity impacts on agrobiodiversity in three coastal, rural villages of Bangladesh. Ocean Coast Manag 54(6):455-468

Schaap MG, Leij FJ, Van Genuchten MT (1998) Neural network analysis for hierarchical prediction of soil hydraulic properties. Soil Sci Soc Am J 62(4):847-855
Scheelbeek PFD, Chowdhury MAH, Haines A, Alam DS, Hoque MA, Butler AP, Khan AE, Mojumder SK, Blangiardo MAG, Elliott P et al (2017) Drinking water salinity and raised blood pressure: evidence from a cohort study in coastal Bangladesh. Environ Health Perspect 125(5):057007-057001

Simunek J, van Genuchten MT, Sejna M (2008) Development and applications of the HYDRUS and STANMOD Software packages and related codes. Vadose Zone J 7(2):587-600

Singh OP (2002) Spatial variation of sea level trend along the Bangladesh coast. Mar Geodesy 25(3):205-212

Sultana S, Ahmed K, Mahtab-Ul-Alam S, Hasan M, Tuinhof A, Ghosh S, Rahman M, Ravenscroft P, Zheng Y (2015) Low-cost aquifer storage and recovery: implications for improving drinking water access for rural communities in coastal Bangladesh. J Hydrol Eng 20(3):B5014007

The World Bank Group (2010) Bangladesh: economics of adaptation to climate change, 20433. The World Bank Group, Washington, DC

Willcocks W (1930) Lectures on the ancient system of irrigation in Bengal and its application to modern problems. University of Calcutta, Calcutta

Worland SC, Hornberger GM, Goodbred SL (2015) Source, transport, and evolution of saline groundwater in a shallow Holocene aquifer on the tidal deltaplain of southwest Bangladesh. Water Resour Res 51(7):5791-5805

Yu W (2010) Implications of climate change for fresh groundwater resources in coastal aquifers in Bangladesh. The Worldbank, Washington DC. Report nr 56556. http://documents.worldbank. org/curated/en/2010/02/12752932/implications-climate-chang e-fresh-groundwater-resources-coastal-aquifers-bangladesh. Accessed 1 June 2017 